\title{
Make it real: Belief in occurrence within episodic future thought
}

\author{
Alexandra Ernst ${ }^{1} \cdot$ Arnaud D'Argembeau $^{1}$
}

Published online: 26 May 2017

(C) Psychonomic Society, Inc. 2017

\begin{abstract}
While the cognitive and neural bases of episodic future thinking are well documented, questions remain as to what gives the sense that an imagined event belongs to one's personal future. Capitalizing on previous research on metacognitive appraisals in autobiographical remembering, we propose that episodic future thinking involves, in varying degrees, a subjective belief in the potential occurrence of imagined future events and we explore the nature and determinants of such belief. To this aim, participants provided justifications for belief in occurrence for a series of past and future events. For each event, they also assessed their subjective feelings (belief in occurrence, autonoetic experience, and belief in accuracy) and rated various characteristics of mental representations that might contribute to these feelings. Results showed that belief in the occurrence of future events mostly related to their integration in a broader autobiographical context, especially their relevance to personal goals and their personal plausibility. We also found that belief in occurrence, autonoetic experience, and belief in accuracy represented distinct subjective appraisals of future events, which depended in part on different determinants. Based on these findings, we propose a new theoretical model of subjective feelings associated with episodic future thinking that conceives of belief in occurrence as arising from metacognitive appraisals that shape the sense that imagined events belong to one's personal future.
\end{abstract}

Alexandra Ernst

Alexandra.Ernst@ulg.ac.be

1 Department of Psychology, Psychology and Neuroscience of Cognition Research Unit, University of Liège, Place des Orateurs 1 (B33), B-4000 Liège, Belgium
Keywords Future thinking $\cdot$ Autobiographical memory Belief in occurrence $\cdot$ Autonoetic experience $\cdot$ Metacognition

Everyone knows the difference between imagining a thing and believing in its existence, between supposing a proposition and acquiescing in its truth.

—William James, The Principles of Psychology, 1890

The human mind has the remarkable ability to momentarily disengage from the immediate environment in order to simulate possible futures, which plays a fundamental role in guiding our decisions and actions (Baumeister, Vohs, \& Oettingen, 2016; Suddendorf \& Corballis, 2007). Over the past decade, important progress has been made in understanding how such future-oriented thoughts are constructed and elaborated (for review, see D'Argembeau, 2015; Schacter et al., 2012; Szpunar, 2010). Research has shown, in particular, that episodic memory plays a critical role in the ability to simulate the future. For example, there is substantial evidence that patients with episodic memory deficits present with difficulties in imagining future events (Klein, Loftus, \& Kihlstrom, 2002; Tulving, 1985), and neuroimaging studies have shown that episodic remembering and future thinking rely on a largely similar brain network (Addis, Wong, \& Schacter, 2007; Botzung, Denkova, \& Manning, 2008). These and related findings have led to the view that episodic future thought is the product of constructive processes, which flexibly select and combine information stored in episodic and semantic memory to create novel event representations (Irish \& Piguet, 2013; Schacter \& Addis, 2007).

Despite these important advances in elucidating the basis of future event construction, a fundamental question that 
remains poorly understood concerns the temporal dimension of episodic future thought. Research indeed suggests that event simulation relies on similar constructive processes irrespective of whether or not imagined scenarios are located in time (de Vito, Gamboz, \& Brandimonte, 2012; Hassabis, Kumaran, Vann, \& Maguire, 2007; Hassabis \& Maguire, 2009), which raises the question of the basis of the subjective "futureness" of prospective thought. What makes one believe that an imagined event refers to something that might happen in one's personal future rather than, say, a mere fantasy? This subjective sense may not be an intrinsic property of imagined events (Klein, 2016), but may instead arise from attributions that we make about our mental experiences (Johnson, 2006). For example, event simulations may be perceived as belonging to our personal future because they are consistent with our expectations and knowledge about ourselves and our life (D'Argembeau, 2016). To date, however, the nature and determinants of these attribution processes remain to be investigated in detail.

An interesting conceptual framework for addressing this question comes from research on the metacognitive processes underlying the subjective experience of remembering past events. There is substantial evidence that the tagging of a mental representation as a memory of a past event results from attributional processes that occur at the time of retrieval (Johnson, Hashtroudi, \& Lindsay, 1993; Rubin, 2006). Research has shown, in particular, that belief in occurrence - the subjective feeling that an event genuinely occurred in the past - is the product of metacognitive appraisals of multiple sources of information available at the time an event is remembered (Scoboria et al., 2014). Although such belief is usually assumed to be associated with recollection (the mental reexperience of the event), these two subjective features are dissociable, as is for example demonstrated by the phenomenon of nonbelieved memories - memories that were once believed to be genuine but are no longer believed, despite the event continues to be vividly recollected (Brédart \& Bouffier, 2016; Mazzoni, Scoboria, \& Harvey, 2010). Furthermore, Scoboria and colleagues (Scoboria et al., 2014; Scoboria, Talarico, \& Pascal, 2015) have demonstrated that recollection and belief in occurrence form distinct latent constructs that are predicted by different variables. Belief in occurrence is strongly influenced by the personal plausibility of events, their rehearsal, and their link to other remembered events, while recollection is mainly predicted by properties of mental representations, such as perceptual details and emotion intensity. Because belief in occurrence is partly shaped by the presence of recollection, common predictors have also been identified, including the personal importance of events and recall of spatial setting (Scoboria et al., 2014; Scoboria, Talarico, et al., 2015).

Recent studies have also revealed that belief in occurrence is distinct from metacognitive appraisals that assess the degree to which the content of the memory corresponds to what happened in the past-referred to as belief in accuracy (Rubin, 2006; Scoboria \& Pascal, 2016; Scoboria, Talarico, et al., 2015). Belief in occurrence and belief in accuracy arise from different autobiographical judgments, the former examining whether an event occurred to the self in the past, and the latter evaluating the correspondence between remembered contents and what was experienced at the time of the event. In other words, the distinction between belief in occurrence and belief in accuracy corresponds to the difference between asking "Did this event occur?" and "Am I remembering this event in the way that it occurred?" (Scoboria, Talarico, et al., 2015). Although conceptually distinct, recollection and belief in accuracy are typically closely related (especially for believed memories), and both are strongly predicted by the presence of perceptual details when remembering (Scoboria \& Pascal, 2016; Scoboria, Talarico, et al., 2015). Taken together, these studies on metacognitive appraisals in autobiographical memory have established that the subjective sense that an event occurred in the past is not an intrinsic property of memories but results from inferential processes that shape judgments of occurrence, recollection, and accuracy.

In the present study, we capitalize on this work on metacognitive appraisals in autobiographical remembering to investigate the nature and determinants of the subjective futureness of prospective thought - the sense that an imagined event belongs to our personal future. Although our beliefs about past and future events differ in epistemic status (for the obvious reason that the latter have yet to happen; Perrin, 2016), we propose that episodic future thoughts are associated, in varying degrees, with a subjective sense or belief that the imagined event will materialize in the future (akin to belief in occurrence) and that, as for memories, this sense reflects metacognitive appraisals based on a range of information available at the time the event is imagined. This notion of belief in future occurrence has been previously examined in the specific context of gambling behavior (Scoboria \& Wilson, 2011), but its general role in episodic future thinking and its determinants remain to be investigated in detail.

Judgments of belief in occurrence might involve both common and distinct bases for past and future events. For example, for past events, remembered details and the quality of mental representations may be important clues for belief in occurrence (Scoboria et al., 2014; Scoboria, Talarico, et al., 2015), whereas this might not necessarily be the case for future events (e.g., one can imagine something very vividly without believing that it will happen). Material evidence (such as pictures or videos) and social feedback may also be important reasons for believing or not believing in the occurrence of past events (Brédart \& Bouffier, 2016; Scoboria, Boucher, \& Mazzoni, 2015), whereas these elements may be less available (if at all) for future events. On the other hand, belief in the occurrence of future events may mainly rely on their personal 
plausibility and consistency with our knowledge and expectations about ourselves and our life.

To test these hypotheses, we first conducted a qualitative analysis of the reasons people provide for believing that a particular event happened in the past or might happen in the future (for a similar qualitative approach applied to nonbelieved memories, see Scoboria, Boucher, \& Mazzoni, 2015). Next, to further investigate the contribution of different sources of information to belief in occurrence for past and future events, we examined to what extent variations in degrees of belief across events are predicted by various dimensions that have been previously linked to belief in occurrence for past events, such as properties of mental representations (sensory details, spatial setting), event plausibility, and rehearsal (Scoboria et al., 2014; Scoboria, Talarico, et al., 2015). Moreover, we examined to what extent the integration of future events in a broader autobiographical context (D’Argembeau, 2016; D'Argembeau \& Mathy, 2011) would also contribute to belief in occurrence. Finally, we sought to determine whether the belief in the occurrence of a future event, the sense of preexperiencing this event (here referred to as autonoetic experience; Lehner \& D'Argembeau, 2016), and the belief in content accuracy are judgments that are based on (partly) distinct sources of information, as has been demonstrated for past events (Scoboria \& Pascal, 2016; Scoboria, Talarico, et al., 2015). Overall, our aim was to document the existence of belief in occurrence for future events and to shed some light on the factors that may contribute to the sense that imagined events belong to one's personal future.

\section{Method}

\section{Participants}

Participants were 92 native French speakers ( 45 women; mean age $=28.54$ years, $S D=10.39$; mean education years $=14.00$, $S D=2.01$ ), mainly students at the University of Liège. The sample size was determined a priori in order to have sufficient statistical power (i.e., 80\%) to detect even "small" withinsubjects differences $(d=0.3)$ using an alpha of .05 (two-tailed; Faul, Erdfelder, Lang, Buchner, \& Kiel, 2007) and to obtain unbiased estimates in multilevel regression analyses (Maas \& Hox, 2005). Eight additional participants were excluded due to difficulties in following the instructions $(n=7)$ or the selfreport of a current depression episode $(n=1)$. All participants gave written informed consent and the study was approved by the University of Liège Ethics Committee.

\section{Material and procedure}

Participants were first asked to produce 20 personal events, 10 for the past and 10 for the future (presented in a counterbalanced order) in response to cue words selected from previous studies on autobiographical memory and future thinking (Ernst et al., 2014; Rubin, Schrauf, \& Greenberg, 2003; see Appendix 1 for the full list of cue words). The generated events had to be specific (i.e., associated with a specific spatiotemporal context and lasting no more than a day), and examples were provided to ensure participants' understanding of the notion of specificity. There was no instruction on the temporal distance of events. For each event, participants provided a short title summarizing the event and then described the spatial context of the event and their age at the time of the event; this enabled us to verify the specificity of reported events.

After all past and future events had been produced, justifications for beliefs in the occurrence of these events were collected. For each event, participants were asked to describe what makes them feel that this event belongs to their past or future, what makes them think that the event happened in the past or will happen in the future. It was specified that there is no right or wrong answer and that we were simply interested in learning about what gives them the sense that the event happened in the past or will happen in the future. Participants were also asked to tell everything that came to their mind when considering their belief in occurrence. Participants' answers were audio-recorded and later transcribed for scoring.

After having answered this open-ended question about belief in occurrence, participants completed a series of ratings using 7-point Likert scales (see Appendix 2). First, subjective feelings when remembering or imagining the event were assessed using four rating scales that were adapted from previous studies on autobiographical memory or future thinking (D'Argembeau \& Van der Linden, 2012; Lehner \& D'Argembeau, 2016; Rubin et al., 2003; Scoboria, Talarico, et al., 2015): one item for belief in occurrence, one item for belief in accuracy, and two items for autonoetic experience (one for mental time travel and one for the feeling of (p)reexperiencing the event). Second, several rating scales assessed phenomenological characteristics of mental representations and event features that might contribute to belief in occurrence and other subjective feelings (D'Argembeau \& Van der Linden, 2012; Lehner \& D'Argembeau, 2016; Rubin et al., 2003; Scoboria et al., 2014; Scoboria, Talarico, et al., 2015; Sutin \& Robins, 2007): the amount of sensory details, the clarity of location, the familiarity of persons and objects involved in the event, the personal importance of the event, its emotional valence and emotional intensity, the extent to which it is related to other personal events, its general plausibility (i.e., the judgment that an event could have occurred or has the potential to occur to people in general), and its personal plausibility (i.e., the judgment that an event could have occurred or has the potential to occur to the self; Scoboria, Mazzoni, Kirsch, \& Relyea, 2004). Finally, participants rated the 
Table 1 Types and categories of justification provided for belief in the occurrence of past and future events

\begin{tabular}{|c|c|c|}
\hline $\begin{array}{l}\text { Type and category of } \\
\text { justification }\end{array}$ & Description & Examples \\
\hline \multicolumn{3}{|l|}{ Personal knowledge } \\
\hline Link with other events & $\begin{array}{l}\text { The event is linked to another specific event, a } \\
\text { routine/generic } \\
\text { event, or a life period. }\end{array}$ & $\begin{array}{l}\text { "I also watched the last Star Wars movie with my friend } \\
\text { Julie" } \\
\text { "We used to go to the Barbarian pub every Friday" } \\
\text { "This will happen during my stay in Budapest" }\end{array}$ \\
\hline Personal characteristics & $\begin{array}{l}\text { The event is linked to personal characteristics such as } \\
\text { self-images, personality traits, values, autobiographical } \\
\text { facts, or any other enduring characteristics describing } \\
\text { oneself. }\end{array}$ & $\begin{array}{l}\text { "I am a musician" } \\
\text { "Family is important to me" } \\
\text { "I always knew what I wanted to do in my life" }\end{array}$ \\
\hline Goals & $\begin{array}{l}\text { Reference to personal goals, wishes, or internal } \\
\text { motivations. } \\
\text { This category differs from the Commitment category } \\
\text { (see } \\
\text { below) in that it refers to self-driven goals, which are not } \\
\text { primarily initiated by external (e.g., material, social) } \\
\text { sources. }\end{array}$ & $\begin{array}{l}\text { "I want to be a psychologist" } \\
\text { "I hope I will see her" } \\
\text { "I made my dream of swimming with turtles come true" }\end{array}$ \\
\hline \multicolumn{3}{|l|}{ General knowledge } \\
\hline Knowledge about others & $\begin{array}{l}\text { Description of personal characteristics of other persons, } \\
\text { including their self-images, personality traits, values, or } \\
\text { autobiographical facts. }\end{array}$ & $\begin{array}{l}\text { "She is a lawyer" } \\
\text { "My cousin lives in Japan" } \\
\text { "My father is passionate about literature" }\end{array}$ \\
\hline Knowledge about the world & $\begin{array}{l}\text { Reference to semantic information and general knowledge } \\
\text { about the world. }\end{array}$ & $\begin{array}{l}\text { "It is easier to go to Brussels by train than by car" } \\
\text { "It is difficult to find a job" } \\
\text { "This is really expensive" }\end{array}$ \\
\hline \multicolumn{3}{|l|}{ Event-based knowledge } \\
\hline Event detail & $\begin{array}{l}\text { Episodic details about the event, including people, } \\
\text { perceptual information, emotion, location, and so on. }\end{array}$ & $\begin{array}{l}\text { "I was wearing my blue dress" } \\
\text { "We will eat spaghetti in an Italian restaurant" } \\
\text { "It was a sunny day" }\end{array}$ \\
\hline Temporal location & $\begin{array}{l}\text { Any information that contributes to the temporal location } \\
\text { of the event (from vague information about temporal } \\
\text { distance to the exact date of the event) }\end{array}$ & $\begin{array}{l}\text { "This will happen very soon" } \\
\text { "The wedding of my friend is on the 18th of June" } \\
\text { "I have defended my thesis two years ago" }\end{array}$ \\
\hline Commitment & $\begin{array}{l}\text { Obligations and already planned events, things } \\
\text { involving an external constraint or a commitment. }\end{array}$ & $\begin{array}{l}\text { "It's the wedding of my best friend and I already } \\
\text { confirmed my presence" } \\
\text { "I have to go to this meeting" } \\
\text { "My car was down, so I had no choice to change it" }\end{array}$ \\
\hline \multicolumn{3}{|l|}{ External information } \\
\hline Material evidence & $\begin{array}{l}\text { Any verifiable, external, concrete element that confirms } \\
\text { the occurrence of the event. }\end{array}$ & $\begin{array}{l}\text { "I have pictures of this moment" } \\
\text { "I have already booked my flight" } \\
\text { "I still have the book" }\end{array}$ \\
\hline Sharing & $\begin{array}{l}\text { The event has been shared, rehearsed, or evoked } \\
\text { with (an)other person(s) }\end{array}$ & $\begin{array}{l}\text { "We still laugh about it at each family dinner" } \\
\text { "I organize this party with my best friend, so we } \\
\text { often talk about it" } \\
\text { "I talked about it with my sister" }\end{array}$ \\
\hline Metacognitive judgments & $\begin{array}{l}\text { Metacognitive judgments about properties of events } \\
\text { or their mental representation, which are used to justify } \\
\text { event occurrence. }\end{array}$ & $\begin{array}{l}\text { "I can imagine this scene with a lot of details" } \\
\text { "That's a very unusual event" } \\
\text { "I see it clearly in mind" }\end{array}$ \\
\hline Emotion $^{\mathrm{a}}$ & $\begin{array}{l}\text { Information regarding the emotional state induced by the } \\
\text { evocation of the event. }\end{array}$ & $\begin{array}{l}\text { "Speaking about this makes me sad" } \\
\text { "I feel nostalgic when I think about this day" }\end{array}$ \\
\hline
\end{tabular}

${ }^{a}$ This category was finally excluded from the analyses due to its low frequency of use

frequency with which they experience similar events in their everyday life, the frequency with which they previously thought and talked about the event, and the event's subjective temporal distance (i.e., the feeling that the event is temporally close or distant from the present, regardless of its objective moment of occurrence).
Events were presented one at a time (in the same order as they had been initially produced) and, for each event, participants completed all questions (the openended question and rating scales) before moving to the next event. All instructions and measures were presented in French. 


\section{Scoring}

To investigate the content of justifications provided for belief in occurrence, we developed a scoring procedure using both a theoretically informed and data-driven approach to ensure that the final coding scheme is representative of participants' answers. This approach followed guidelines and recommendations for the development of qualitative data analysis (see, for instance, Braun \& Clarke, 2006; Hruschka et al., 2004).

A first version of the scoring scheme was partly based on the work of Scoboria, Boucher, and Mazzoni (2015), who developed a scoring procedure aiming at examining reasons for withdrawing belief in memories. We adapted this procedure for our current aim (i.e., to explore the reasons for believing in the occurrence of memories) and extended it to future-oriented thought, thus including justifications that could potentially be relevant for future events (e.g., goals and commitment). Then, the first author read a subset of transcripts (a random sample of 100 past events and 100 future events, which correspond to approximately $11 \%$ of the transcripts) to assess the relevance and feasibility of the initial scoring procedure. This led us to include additional categories of justifications that were not represented in the first version of the scoring scheme but were identified when reading the transcripts (i.e., temporal location and knowledge about the world). The scoring procedure was tested once again on an additional sample of participants (i.e., 600 past events and 600 future events, which correspond to about $65 \%$ of the transcripts) before validation. Here, our criteria to validate the scoring scheme was that any event should at least be classifiable in one category of justification. The final scoring scheme included seven types of justifications, each of them containing several categories (see Table 1 for a complete description and examples).

The first type of justification involved the use of personal knowledge (such as references to other events, personal characteristics, and goals) for linking and integrating the event with one's personal characteristics and life story. The second type of justification involved the use of general knowledge (about others and the world) to support belief in occurrence. The third type of justification, referred to as commitment, involved externally motivated behaviors or events that were already planned (or in which the person was already engaged). The fourth type of justification (event-based knowledge) involved the use of specific details about the event or its temporal location to support belief in occurrence. The fifth type of justification identified the use of external information (including material evidence and sharing the event with others). The sixth type of justification involved metacognitive judgments about some properties of events or mental representations (e.g., my memory is very clear). Finally, the last type of justification (Emotion) referred to the emotional state induced by the evocation of the event. Note that more than one type or category of justifications could be used for a given event. For each event, we coded the absence $(=0)$ or the presence $(=1)$ of each category of justification.

As a final validation of the coding scheme, the interrater reliability was verified for each category of justification. The first author rated the entire body of transcripts and the second author rated a subsample of transcripts (corresponding to a random selection of $10 \%$ of transcripts). Interrater agreement was high for all categories of justification, with percentages of agreement ranging from $90 \%$ to $98 \%$. Cohen's kappa was 0.84 for link with other events, 0.74 for personal characteristics, 0.89 for goals, 0.86 for event detail, 0.94 for temporal location, 0.92 for sharing, 0.87 for material evidence, and 0.84 for metacognitive judgments. The kappa coefficients for the categories commitment, knowledge about others, knowledge about the world, and emotion were not computed because their marginal distributions were not uniform (Von Eye \& Von Eye, 2008).

\section{Results}

A total of 919 past and 920 future events were reported by the participants. Prior to data analysis, the specificity of events was checked using the following criteria (Addis, Cheng, Roberts, \& Schacter, 2011; Holland, Addis, \& Kensinger, 2011): An event was considered "specific" if it referred to a unique event occurring at a particular time and place, and lasting no longer than a day; repeated (e.g., weekly lab seminars) and extended (e.g., a vacation that lasted for a week) events were considered "nonspecific." Nonspecific events were excluded, leaving 893 past events and 830 future events for the analyses.

We first examined the content of justifications that were spontaneously generated by participants to support belief in occurrence for past and future events. Then, we investigated to what extent past and future events differ in degrees of belief in occurrence and other subjective characteristics, such as autonoetic consciousness and belief in accuracy. Finally, we sought to identify the predictors of belief in occurrence, autonoetic experience, and belief in accuracy for past and future events.

\section{Justifications for belief in occurrence}

The proportion of memories and future thoughts involving each category of justification is shown in Fig. 1. As can be seen, event details were most frequently used to justify belief in the occurrence of past events, followed by personal characteristics, material evidence, links with other events, and metacognitive judgments. For future events, most justifications referred to goals, personal characteristics, links with other events, and temporal location. References to emotion were 


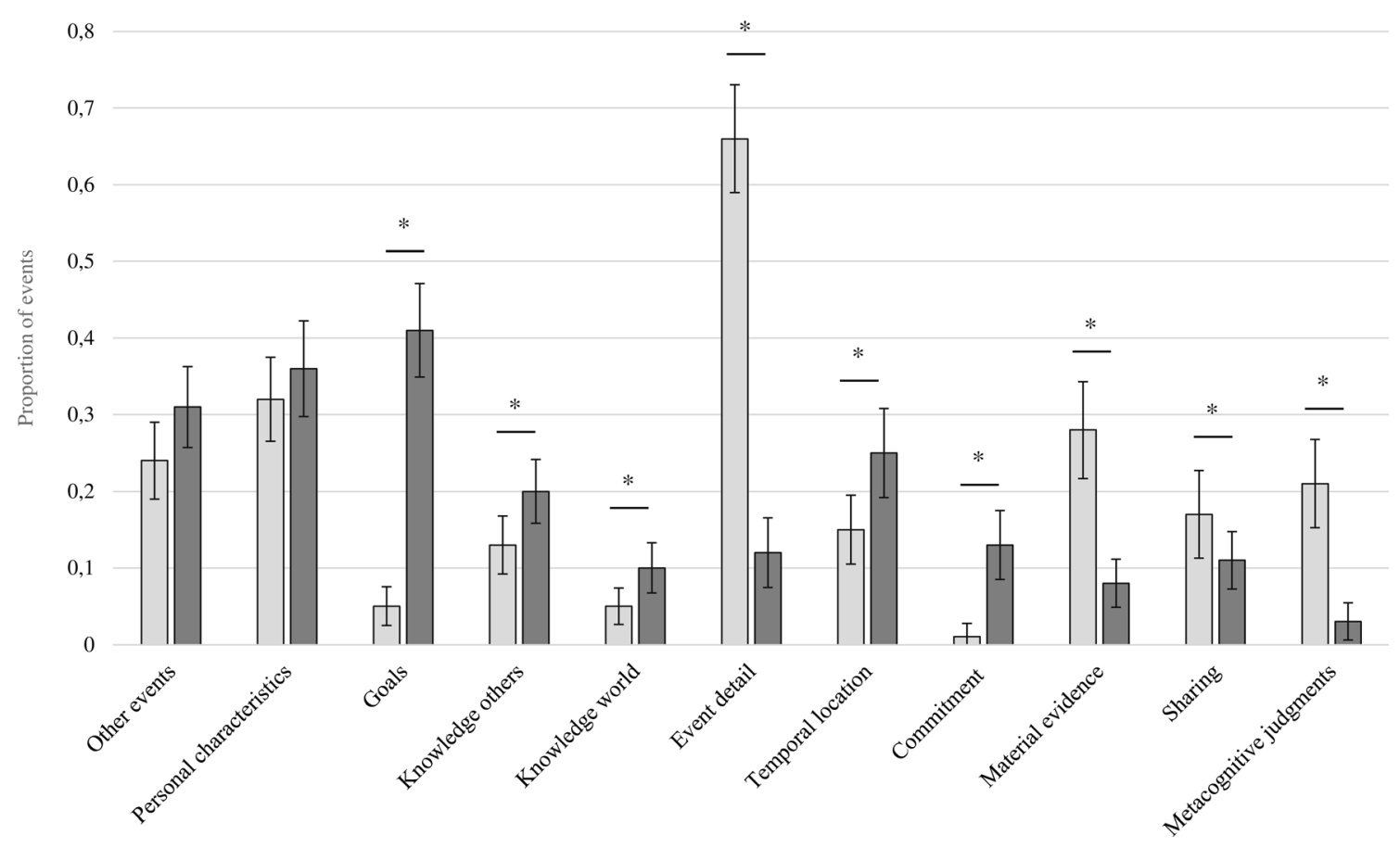

$\square$ Past $\square$ Future

Fig. 1 Proportion of events involving each category of justifications used to support belief in occurrence for past and future events. Error bars show 95\% confidence intervals for within-subject designs (O'Brien \&

very infrequent for both past and future events $(<5 \%)$, and were thus excluded from the subsequent analyses.

A repeated-measures ANOVA, with temporal direction (past, future) and categories of justification (11 subcategories) as within-subjects factors showed a main effect of temporal direction, $F(1,91)=10.07, p=.002, \eta_{\mathrm{p}}{ }^{2}=0.10$, a main effect of categories of justification, $F(10,910)=56.43, p<.001, \eta_{\mathrm{p}}{ }^{2}$ $=0.38$, and a significant interaction, $F(10,910)=115.66, p<$ $.001, \eta_{\mathrm{p}}{ }^{2}=0.56$. Follow-up comparisons $(t$ tests for dependent samples, with a Bonferroni correction) were then performed to examine differences between the past and future in the frequency of use of the different categories of justification. This revealed three main results. First, we found that personal characteristics were used to a similar extent to justify the occurrence of past and future events, $t(91)=-1.50, p=0.14, d=0.19$. Second, some categories were more frequently invoked for past than future events, including event detail, $t(91)=21.47, p<$ $.001, d=2.45$, sharing, $t(91)=2.99, p=.003, d=0.37$, material evidence, $t(91)=8.85, p<.001, d=1.25$, and metacognitive judgments, $t(91)=8.86, p<.001, d=1.18$. Conversely, the following justifications were more frequently used for future than past events: temporal location, $t(91)=-4.78, p<.001, d=$ 0.50 , commitment, $t(91)=-8.00, p<.001, d=1.21$, goals, $t(91)$ $=-16.02, p<.001, d=2.10$, knowledge about others, $t(91)=-$ $4.24, p<.001, d=0.47$, and knowledge about the world, $t(91)$ $=-4.20, p<.001, d=0.50 ;$ links to other events were also more
Cousineau, 2014). * Indicates differences that remained significant after applying a correction for multiple comparisons using the Bonferroni procedure

frequent for future events, but the difference failed to reach statistical significance when a Bonferroni correction was used, $t(91)=-2.76, p=.007, d=0.33$.

\section{Subjective feelings and event properties of past and future events}

The preceding analyses showed that the types of justifications that participants spontaneously used to support belief in occurrence differed in part between past and future events. Next, we examined whether past and future events differed in degrees of belief in occurrence and other subjective feelings. Ratings of belief in occurrence, autonoetic experience, and belief in accuracy were averaged across events in each temporal direction. Since the two items measuring autonoetic experience were highly correlated with each other (the mean correlations at the within-participants level were 0.76 for past events and 0.78 for future events), data were averaged to form an index of autonoetic experience. As can be seen from Table 2, past events were associated with higher degrees of belief in occurrence, autonoetic experience, and belief in accuracy than future events.

We also examined whether past and future events differed in terms of other phenomenological characteristics and event features (see Table 2). The two items assessing event rehearsal were strongly correlated (the mean correlations at the within- 
Table 2 Mean ratings (and standard deviations) of subjective feelings and event features of past and future events

\begin{tabular}{lllll}
\hline & Past & Future & $t(91)$ & $p$ \\
\hline Subjective feelings & & & & \\
$\quad$ Belief in occurrence & $6.32(.60)$ & $5.07(.74)$ & 18.15 & $<.001 *$ \\
Autonoetic experience & $5.14(.80)$ & $4.23(.87)$ & 11.44 & $<.001 *$ \\
Belief in accuracy & $5.41(.77)$ & $3.97(.84)$ & 17.68 & $<.001 *$ \\
Event features & & & 1.84 \\
Sensory details & $4.82(.79)$ & $3.76(.90)$ & 11.82 & 1.08 \\
Clarity of location & $5.61(.68)$ & $4.04(.96)$ & 16.09 & $<.001 *$ \\
Familiarity & $4.68(.81)$ & $4.00(1.04)$ & 6.80 & $<.001 *$ \\
Personal importance & $4.07(1.04)$ & $4.59(1.10)$ & -5.26 & $<.001 *$ \\
Emotional valence & $1.04(.76)$ & $1.67(.63)$ & -6.81 & $<.001 *$ \\
Emotional intensity & $4.42(.81)$ & $4.54(1.02)$ & -1.43 & $<.001 *$ \\
Other personal events & $3.35(1.05)$ & $3.71(.98)$ & -3.97 & .15 \\
Personal Plausibility & $5.85(.94)$ & $5.40(.75)$ & .72 \\
General plausibility & $4.81(.73)$ & $4.92(.85)$ & .49 \\
Similarity & $2.53(.64)$ & $2.60(.72)$ & -1.20 & .90 \\
Rehearsal & $3.57(.74)$ & $3.52(.93)$ & -0.83 & .13 \\
Subjective temporal distance & $4.00(.87)$ & $3.74(.79)$ & 0.44 & .35 \\
Objective temporal distance (in years) & $7.34(5.99)$ & $2.67(2.74)$ & 2.29 & .23 \\
\hline
\end{tabular}

Note. * Indicates differences that remained significant after applying a correction for multiple comparisons using the Bonferroni procedure. The objective temporal distance of past and future events was calculated by counting the number of years between participants' current age and their age at the time of the events

participants level were 0.76 for past events and 0.72 for future events) and were thus averaged to form a rehearsal index. In line with previous studies on autobiographical memory and future thinking (e.g., Addis, Wong, \& Schacter, 2008; Berntsen \& Jacobsen, 2008; D'Argembeau \& Van Der Linden, 2004; D'Argembeau \& Van der Linden, 2006; McDonough \& Gallo, 2010; Spreng \& Levine, 2006), we found that past events were associated with more sensory details, a clearer spatial setting, and a higher temporal distance, whereas future events were judged more important and more positive.

\section{Predicting subjective feelings associated with past and future events}

Thus far, we have shown that belief in occurrence is justified on partly different reasons for past and future events and that the strength of belief in occurrence and other subjective feelings is higher for the past than the future. Our next goal was then to investigate whether belief in occurrence and other subjective feelings are predicted by similar event properties for memories and future thoughts. Previous studies have shown that multiple variables contribute to subjective feelings associated with remembering past events (Fitzgerald \& Broadbridge, 2013; Rubin et al., 2003; Scoboria et al., 2014; Scoboria, Mazzoni, Kirsch, \& Relyea, 2004; Scoboria \& Pascal, 2016; Scoboria, Talarico, et al., 2015) and imagining future events
(D’Argembeau \& Van der Linden, 2012). Based on this prior work, we identified three types of variables that could contribute to belief in occurrence and other subjective feelings: sensory-perceptual characteristics of mental representations (i.e., amount of sensory details, clarity of location), the autobiographical context of events (i.e., personal importance, link with other events, personal plausibility), and rehearsal.

Before looking at the bivariate associations between these variables and subjective feelings, we first examined to what extent belief in occurrence, autonoetic experience, and belief in accuracy were related to each other. Due to their hierarchical structure (i.e., the sampled events were nested within participants), data were analyzed using multilevel modeling (Goldstein, 2011), with events as Level 1 units and participants as Level 2 units; all analyses were performed using MLwiN (Rasbash, Charlton, Browne, Healy, \& Cameron, 2009). For past events, we found that belief in occurrence correlated with autonoetic experience $(r=.58, p<.001)$ and belief in accuracy $(r=.54, p<.001)$ at the within-participants level (i.e., variations among events); autonoetic experience and belief in accuracy were also correlated with each other $(r=.69, p<.001)$. The magnitude of these correlations is comparable to those reported in previous studies on subjective feelings associated with believed memories (Scoboria \& Pascal, 2016; Scoboria, Talarico, et al., 2015). Similar correlations between subjective feelings were observed for future events: belief in occurrence correlated with autonoetic 
experience $(r=.54, p<.001)$ and belief in accuracy $(r=.51, p$ $<.001)$, and autonoetic experience correlated with belief in accuracy $(r=.63, p<.001)$.

The bivariate associations between subjective feelings and the event properties of interest in this study are presented in Table 3. Given that subjective feelings were related to several event properties, the independent contribution of each variable was then assessed.

\section{Predicting belief in occurrence}

The bivariate associations between belief in occurrence and event features are presented in Table 3. These analyses showed that variables referring to the sensory-perceptual characteristics, autobiographical context, and rehearsal of events were all significantly related to belief in occurrence, for both the past and the future. A series of multilevel regression models were constructed to examine the unique contribution of these predictors to belief in occurrence. Each category of predictors (i.e., sensory-perceptual characteristics, autobiographical context, and rehearsal) were successively introduced in the regression models to examine their specific contribution and to determine the best model for predicting belief in occurrence. These analyses were performed separately for past and future events.

With respect to past events, sensory-perceptual characteristics were first introduced as predictors in a regression model with belief in occurrence as outcome variable. This model was statistically significant (likelihood ratio, $\mathrm{LR}=206.87, d f=2, p$ $<.001$ ), and sensory details and clarity of location were both significant predictors of belief in occurrence. The variables referring to autobiographical context (personal importance, link with other events, personal plausibility) were then added to this model, which resulted in a significantly better fit $(\mathrm{LR}=53.55$, $d f=3, p<.001)$; personal importance and personal plausibility both uniquely contributed to belief in occurrence, whereas the link with other events $\operatorname{did} \operatorname{not}(Z=0.53, p=.58)$ and was thus removed from the model. Finally, adding rehearsal to the latter model resulted in a significantly better fit $(\mathrm{LR}=12.52, d f=1, p$ $<.001)$ and the effect of all variables remained significant. Overall, the best and most parsimonious model was to use sensory details, location clarity, personal importance, personal plausibility, and rehearsal to predict belief in occurrence (see Table 4). This model accounted with $73 \%$ of the withinparticipants variance in belief in occurrence.

For future events, sensory-perceptual characteristics were first entered as predictors in a regression model with belief in occurrence as outcome variable. This model was statistically significant $(\mathrm{LR}=133.79, d f=2, p<.001)$, and both sensory details and clarity of location significantly contributed to the model. Next, we added the variables relating to autobiographical context to the model, which resulted in a significantly better fit $(\mathrm{LR}=271.98, d f=3, p<.001)$. Personal importance and personal plausibility were both significant predictors of belief in occurrence; the link with other events did not uniquely contribute to belief in occurrence $(Z=1.13, p=.26)$ and was thus removed from the model. In addition, the contribution of sensory details to the model was no longer significant $(Z=0.80, p=.42)$, which suggests that the influence of sensory details on belief in occurrence was mediated by the personal importance and plausibility of future events. Finally, the inclusion of rehearsal in the model resulted in a significantly better fit ( $\mathrm{LR}=22.98, d f=1, p<.001)$. Overall, the best and most parsimonious model was to use location clarity, personal importance, personal plausibility, and rehearsal to predict belief in the occurrence of future events (see Table 4). This model accounted with $58 \%$ of the within-participants variance in belief in occurrence.

\section{Predicting autonoetic experience}

The bivariate associations between autonoetic experience and event features are presented in Table 3. Autonoetic experience

Table 3 Bivariate associations between subjective feelings and event features

\begin{tabular}{|c|c|c|c|c|c|c|}
\hline & \multicolumn{3}{|l|}{ Past } & \multicolumn{3}{|l|}{ Future } \\
\hline & $\begin{array}{l}\text { Belief in } \\
\text { occurrence }\end{array}$ & $\begin{array}{l}\text { Autonoetic } \\
\text { experience }\end{array}$ & $\begin{array}{l}\text { Belief in } \\
\text { accuracy }\end{array}$ & $\begin{array}{l}\text { Belief in } \\
\text { occurrence }\end{array}$ & $\begin{array}{l}\text { Autonoetic } \\
\text { experience }\end{array}$ & $\begin{array}{l}\text { Belief in } \\
\text { accuracy }\end{array}$ \\
\hline \multicolumn{7}{|c|}{ Sensory-perceptual characteristics } \\
\hline Sensory details & $.40[.34, .46] * *$ & $.68[.63, .72] * *$ & $.62[.57, .67] * *$ & $.32[.25, .38] * *$ & $.61[.55, .66] * *$ & $.45[.39, .52] * *$ \\
\hline Clarity of location & $.39[.34, .45] * *$ & $.55[.50, .60] * *$ & $.53[.47, .58] * *$ & $.37[.30, .43] * *$ & $.49[.43, .54] * *$ & $.48[.42, .54] * *$ \\
\hline \multicolumn{7}{|l|}{ Autobiographical context } \\
\hline Personal importance & $.27[.20, .33] * *$ & $.38[.31, .44] * *$ & $.25[.19, .32] * *$ & $.26[.20, .33] * *$ & $.28[.40, .52] * *$ & $.19[.12, .26] * *$ \\
\hline $\begin{array}{l}\text { Link with other personal } \\
\text { events }\end{array}$ & $.21[.14, .28] * *$ & $.29[.22, .35] * *$ & $.21[.15, .28] * *$ & $.23[.16, .30] * *$ & $.27[.20, .34] * *$ & $.18[.11, .25] * *$ \\
\hline Personal plausibility & $.28[.22, .35] * *$ & $.17[.10, .24] * *$ & $.20[.13, .27] * *$ & $.59[.54, .65] * *$ & $.40[.33, .46] * *$ & $.38[.32, .45] * *$ \\
\hline Rehearsal & $.32[.25, .38] * *$ & $.44[.38, .50] * *$ & $.35[.29, .41] * *$ & $.40[.34, .47] * *$ & $.36[.30, .42] * *$ & $.26[.20, .33] * *$ \\
\hline
\end{tabular}

$* * p<.001$, two-tailed. The $95 \%$ confidence intervals are in brackets 
Table 4 Standardized coefficients from multilevel regression models predicting belief in occurrence, autonoetic experience, and belief in accuracy from sensory-perceptual characteristics (sensory details, clarity of location), autobiographical context (personal importance, link with other events, personal plausibility) and rehearsal

\begin{tabular}{|c|c|c|c|c|c|c|}
\hline \multirow[b]{2}{*}{ Explanatory variables } & \multicolumn{2}{|l|}{ Past } & \multicolumn{4}{|l|}{ Future } \\
\hline & $\begin{array}{l}\text { Belief in } \\
\text { occurrence }\end{array}$ & $\begin{array}{l}\text { Autonoetic } \\
\text { experience }\end{array}$ & $\begin{array}{l}\text { Belief in } \\
\text { accuracy }\end{array}$ & $\begin{array}{l}\text { Belief in } \\
\text { occurrence }\end{array}$ & $\begin{array}{l}\text { Autonoetic } \\
\text { experience }\end{array}$ & $\begin{array}{l}\text { Belief in } \\
\text { accuracy }\end{array}$ \\
\hline \multicolumn{7}{|c|}{ Sensory-perceptual characteristics } \\
\hline Sensory details & $.19[.12, .26] * *$ & $.47[.41, .53] * *$ & $.43[.37, .50] * *$ & . & $.39[.33, .45] * *$ & $.20[.14, .27] * *$ \\
\hline Clarity of location & $.19[.13, .26] * *$ & $.20[.14, .25] * *$ & $.23[.17, .29] * *$ & $.19[.13, .26] * *$ & $.21[.16, .27] * *$ & $.31[.24, .37] * *$ \\
\hline \multicolumn{7}{|c|}{ Autobiographical context } \\
\hline Personal importance & $.08[.02, .14] *$ & $.14[.09, .19] * *$ & . & $.07[.01, .13] *$ & $.07[.01, .12] *$ & $0.06[.00, .12] *$ \\
\hline $\begin{array}{l}\text { Link with other } \\
\text { personal events }\end{array}$ & . & . & . & . & . & . \\
\hline Personal Plausibility & $.18[.12, .24] * *$ & . & $.08[.02, .13] *$ & $.46[.11, .52] * *$ & $.16[.11, .21] * *$ & $.22[.16, .28] * *$ \\
\hline Rehearsal & $.12[.05, .18] * *$ & $.12[.07, .17] * *$ & $.08[.02, .13] *$ & $.16[.09, .22] * *$ & $.12[.06, .17] * *$ & . \\
\hline
\end{tabular}

$* p<.05$, two-tailed; $* * p<.001$, two-tailed. The $95 \%$ confidence intervals are in brackets.

was significantly related to sensory-perceptual characteristics, autobiographical context, and rehearsal of events. To examine the unique contribution of these predictors to autonoetic experience, a series of multilevel regression models were constructed. Each category of predictors (i.e., sensory-perceptual characteristics, autobiographical context, and rehearsal) were successively introduced in the regression models to examine their specific contribution and to determine the best model for predicting autonoetic experience. Past and future events were analyzed separately.

Regarding past events, sensory-perceptual characteristics were first introduced as predictors in a model with autonoetic experience as outcome variable. This model was statistically significant $(\mathrm{LR}=649.51, d f=2, p<.001)$, and sensory details and clarity of location both uniquely contributed to autonoetic experience. The variables referring to autobiographical context (personal importance, link with other events, personal plausibility) were then added to this model, which resulted in a significantly better fit $(\mathrm{LR}=56.05, d f=3, p<.001)$; personal importance of events showed a unique contribution to autonoetic experience, whereas the personal plausibility of events $(Z=0.40, p=.68)$ and their link with other personal events $(Z=0.73, p=.46)$ did not and were thus removed from the model. Finally, adding rehearsal to the model resulted in a significantly better fit $(\mathrm{LR}=21.79, d f=1, p<.001)$ and the effect of all variables remained significant. Thus, the best and most parsimonious model was to use sensory details, location clarity, personal importance and rehearsal to predict autonoetic experience (see Table 4). This model accounted for $34 \%$ of the within-participants variance in autonoetic experience for past events.

Turning to future events, a first model including sensoryperceptual characteristics as predictors was statistically significant $(\mathrm{LR}=449.981, d f=2, p<.001)$, and both sensory details and location clarity showed a significant contribution to the prediction of autonoetic experience. Adding the variables referring to autobiographical context (personal importance, personal plausibility and link with other events) to the model resulted in a significantly better fit $(\mathrm{LR}=78.00, d f=3, p<$ .001). While personal importance and personal plausibility were both significant predictors of autonoetic experience, the link with other events did not show a unique contribution to the model $(Z=1.82, p=.07)$ and was removed from the analysis. Finally, introducing rehearsal in the model resulted in a significantly better fit $(\mathrm{LR}=16.67, d f=1, p<.001)$ and the effect of all variables remained significant. Overall, the best and most parsimonious model for predicting autonoetic experience for future events was to use sensory details, location clarity, personal importance, personal plausibility and rehearsal (see Table 4), which accounted for $53 \%$ of the withinparticipants variance in autonoetic experience.

\section{Predicting belief in accuracy}

The bivariate associations between belief in accuracy and event features are presented in Table 3. Variables referring to the sensory-perceptual characteristics, autobiographical context, and rehearsal of events were all significantly related to belief in accuracy, for both past and future events. A series of multilevel regression models were then constructed to examine the unique contribution of these predictors to belief in accuracy. Again, each category of predictors (i.e., sensoryperceptual characteristics, autobiographical context, and rehearsal) were successively added to the regression models to examine their unique contribution and to determine the best model for predicting belief in accuracy. These analyses were performed separately for the past and the future. 
Regarding past events, we first introduced sensoryperceptual characteristics as predictors in a regression model with belief in accuracy as outcome variable. This model was statistically significant $(\mathrm{LR}=504.38, d f=2, p<.001)$ and both sensory details and location clarity provided a unique contribution to belief in accuracy. Autobiographical context was then added to the model, which resulted in a significantly better fit ( $\mathrm{LR}=12.40, d f=3, p=.006$ ); personal plausibility uniquely contributed to the prediction of belief in accuracy, whereas personal importance $(Z=1.83, p=.07)$ and link with other personal events $(Z=-0.03, p=.96)$ did not and were thus dropped out of the model. Adding rehearsal to the model resulted in a significantly better fit ( $\mathrm{LR}=7.42, d f=1, p=$ .006 ), with no effect on the other variables. Overall, the best and most parsimonious model was to use sensory details, location clarity, personal plausibility, and rehearsal to predict belief in accuracy (see Table 4). This model accounted with $54 \%$ of the within-participants variance in belief in accuracy.

Concerning future events, the model including the sensoryperceptual characteristics of events was also significant (LR = 278.101, $d f=2, p<.001$ ), and sensory details and clarity of location were both significant predictors of belief in accuracy. Adding autobiographical context to the model resulted in a significantly better fit ( $\mathrm{LR}=62.71, d f=3, p<.001)$; personal importance and personal plausibility both uniquely contributed to the prediction of belief in accuracy, whereas the link with other personal events $(Z=-0.44, p=.66)$ did not and was thus removed from the model. Finally, the introduction of rehearsal in the model did not result in a significantly better fit (LR = $1.47, d f=1, p=.22$ ). This suggested that the influence of rehearsal on belief in accuracy was mediated by the sensoryperceptual characteristics of events and their connection to autobiographical context. Thus, the best and most parsimonious model was to use sensory details, location clarity, personal importance and personal plausibility to predict belief in accuracy (see Table 4). This model accounted with $62 \%$ of the withinparticipants variance in belief in accuracy for future events.

\section{Discussion}

While important advances have recently been made in elucidating the basis of future event construction, factors that may confer a sense of futureness on imagined events remain poorly understood. In this study, we suggested that belief in occurrence is a key dimension contributing to the sense that imagined events belong to one's personal future. Our findings indicate that such belief arises from attribution processes that rely on multiple sources of information, notably the integration of future events in a broader autobiographical context. Furthermore, we found that belief in occurrence, autonoetic experience, and belief in accuracy for future events represent distinct metacognitive appraisals, which depend in part on different determinants. Our results also extend previous investigations on metamemory appraisals (Rubin et al., 2003; Scoboria et al., 2014; Scoboria \& Pascal, 2016; Scoboria, Talarico, et al., 2015) by showing that belief in occurrence and other subjective feelings are generally stronger for past than future events, and rely on both common and distinct sources of information.

The first goal of this study was to document the existence of belief in occurrence within episodic future thought and to shed some light on its determinants. A qualitative analysis of the reasons provided by participants to justify their belief in the occurrence of future events indicated that they most frequently referred to personal goals, personal characteristics, and other personal events to explain their sense that imagined events will happen in the future. Furthermore, when investigating factors that determine variations in the degree of belief in occurrence across imagined future events (as assessed by rating scales), we found that the autobiographical context of imagined events was a strong predictor of the strength of belief in occurrence. Indeed, personal plausibility - the judgment that an event has the potential to occur to the self (Scoboria et al., 2004) - was the strongest predictor of belief in the occurrence of future events, and personal importance also independently contributed to this subjective sense; the link with other personal events was also related to belief in occurrence, but did not independently contribute to variation in belief when personal importance and plausibility were taken into account. Overall, these results support the view that the subjective sense of futureness within episodic future thought arises, at least in part, from the contextualization of imagined events within one's life story: linking events to autobiographical knowledge (e.g., personal aspirations and expectations about oneself and one's life) might confer a sense of "realness" to imagined futures (D'Argembeau, 2016). In addition, we found that judgments about the occurrence of future events also frequently relied on their temporal location and on commitments to future events. While these two justifications do not explicitly refer to autobiographical knowledge, they suggest that placing events on a personal mental timeline (based on their estimated time of occurrence or external constraints) also contributes to the sense of "realness" of future events.

From a theoretical standpoint, the role of autobiographical context in shaping one's belief in the occurrence of future events fits well with the theory of pragmatic prospection recently proposed by Baumeister et al. (2016). Within this framework, the basic reason for thinking about the future is to guide actions toward desired outcomes. The attribution of personal meaning and the sense of realness of imagined events may increase one's motivation to connect present actions to desired future states, and to organize the sequences of actions necessary to reach these states. As such, an important function of autobiographical knowledge in prospection may be to screen and sort out imagined events that are consistent with 
one's personal situation and expectations from those that are not-thus preventing people to follow unrealistic or unproductive expectations - and to distinguish future events that are effective for reaching desired states from those that are not (Conway, Loveday, \& Cole, 2016).

Consistent with our hypotheses, sensory-perceptual characteristics and the quality of mental representations played a marginal role in shaping belief in the occurrence of future events. Indeed, event details and metacognitive judgments were seldom reported by participants to justify their belief in the occurrence of future events. However, the clarity of imagined locations was a significant predictor of variations in the degree of belief in occurrence across imagined future events. We speculate that this contribution of location clarity to belief in occurrence might be related to the early involvement of spatial setting processes during the construction of mental scenes (Summerfield, Hassabis, \& Maguire, 2010). Indeed, some studies have suggested that the mere intention to mentally construct a scene would involve spatial setting processes that create a spatial context in which an imagined event can unfold and provide an overall coherence to this event (Gronau, Neta, \& Bar, 2008; Hassabis \& Maguire, 2009; Summerfield et al., 2010). It could be that the clearer this contextual frame, the more tangible and real imagined events appear, although this hypothesis remains to be investigated in detail.

Besides the autobiographical context and location clarity of imagined events, a series of additional determinants were involved in shaping the sense of realness associated with episodic future thinking. Participants sometimes used general knowledge about others and the world to justify their belief in the occurrence of future events; this knowledge may provide a general framework that allows people to think about what the future may be like and to appraise the likelihood of future happenings (Szpunar, Spreng, \& Schacter, 2014). Variations in degrees of belief in occurrence were also significantly predicted by the frequency of previous thoughts about imagined future events. In the same vein, Szpunar and Schacter (2013) have previously demonstrated that repeated simulation of future events increased beliefs in the likelihood of events.

While the present findings shed new light on the nature and determinants of the feeling of realness associated with episodic future thought, the relation between the notion of belief in occurrence and judgments of the plausibility or likelihood of events deserves further discussion. Indeed, one could legitimately wonder whether these notions refer to distinct aspects of episodic future thinking or whether they tap into the same construct. Although belief in occurrence and personal plausibility are clearly related (as shown by the present results), we argue that they represent distinct constructs (note that the latter better corresponds to the judgments of likelihood or plausibility that have been used in previous studies of episodic future thought; e.g., De Brigard \& Giovanello, 2012; De Brigard, Giovanello, Stewart, Lockrow, O’Brien, \& Spreng, 2016;
Szpunar \& Schacter, 2013; Weiler, Suchan, \& Daum, 2010). More specifically, we contend that the judgment that an event has the potential to occur to the self (personal plausibility) is not totally superimposable to the subjective feeling that this event happened in the past or will happen in the future (belief in occurrence). Instead, these notions are probably best represented as partly nested constructs (Scoboria et al., 2004): Most believed events are associated with a strong personal plausibility, yet one can believe that an unlikely event has happened in the past or will happen in the future; furthermore, an event can be seen as plausible without the belief that it has happened or will happen. On this view, personal plausibility is an important but not the only or even a necessary determinant of belief in occurrence. The current findings that belief in occurrence was not only predicted by personal plausibility but also by the personal importance of events and the clarity of spatial context provide some empirical support for this view.

Another goal of this study was to explore commonalities and differences in the determinants of belief in occurrence for past and of future events. While our findings support the idea that, as for memories (Johnson et al., 1993; Rubin, 2006), tagging a mental representation as a personal future event results from attributional processes, this judgment seems grounded in partially distinct sources of information for the past and the future. In terms of commonalities, we found that relating events with personal characteristics and linking them with other events were used to the same extent to justify beliefs in past and future events, which is consistent with theoretical views considering that autobiographical knowledge plays a key role in both autobiographical remembering and future thinking (Conway, 2005; D’Argembeau, 2015). Furthermore, although participants rated belief in occurrence as stronger for past than future events, variations in degrees of belief in occurrence were predicted by largely similar determinants for past and future events, including location clarity, rehearsal, personal importance, and personal plausibility (although the contribution of the latter was greater for future than past events). However, a critical difference between the two temporal orientations was the contribution of event details: The amount of sensory details independently contributed to variation in belief in occurrence for past events but not for future events, and participants relied to a greater extent on event details and metacognitive judgments to support belief in occurrence for past than future events. This finding is not surprising considering that remembered details may be diagnostic of the occurrence of a past event, whereas one can imagine an event in detail without necessarily believing that it will happen. As expected, external sources of information (i.e., sharing and material evidence) were also more frequently invoked to support the occurrence of past events. This result likely reflects the social function of remembering (Rasmussen \& Habermas, 2011) and the influence of social feedback on belief in occurrence (Scoboria, Boucher, \& Mazzoni, 2015), 
as well as the greater availability of material evidence such as pictures or souvenirs for past events.

A final question that was considered in the present study was whether belief in occurrence, autonoetic experience, and belief in accuracy represent distinct dimensions of subjective experience while imagining future events, as has been previously demonstrated for memories of past events (Scoboria \& Pascal, 2016; Scoboria, Talarico, et al., 2015). Our findings support this hypothesis by showing that these three metacognitive appraisals were dissociable - albeit moderately correlated - and relied on partly distinct predictors. A striking divergence was the contribution of sensory details to autonoetic experience and belief in accuracy but not to belief in occurrence for future events. This finding is consistent with prior studies demonstrating that autonoetic experience and belief in accuracy overlap to a large extent (at least for believed events) and are generally rooted in the sensoryperceptual qualities of mental representations (D'Argembeau \& Van der Linden, 2012; Lehner \& D'Argembeau, 2016; Scoboria \& Pascal, 2016; Scoboria, Talarico, et al., 2015). ${ }^{1}$ The fact that belief in occurrence was predicted by the event's autobiographical context rather than event details might indicate that people can mentally "try out" multiple versions of an event (Baumeister et al., 2016; Schacter, 2012) without revising their general belief in the occurrence of this event.

Taken together, our results provide novel evidence that the cognitive feelings that accompany episodic future thinking are not intrinsic characteristic of mental representations, but instead arise from metacognitive appraisals. These attributional processes rely on distinct sources of information that shape our judgments about the occurrence of imagined events, the accuracy of represented contents, and associated autonoetic experience. Schematically, these subjective feelings - and in particular the sense that an event will occur in one's personal future - mainly rely on the integration and contextualization of imagined events with autobiographical knowledge and personal expectations. Based on these findings, we propose a new theoretical model of the subjective feelings experienced when imagining one's personal future (illustrated in Fig. 2) in which the sense of realness of future events depends on various sources of information, which are partly common and partly distinct from the sources of information that shape belief in occurrence for past events.

While imagining a detailed and vivid mental scene has thus far been seen as the core of episodic future thinking (de Vito et al., 2012; Hassabis \& Maguire, 2009), the present study adds to growing evidence showing that episodic future thinking involves more than scene construction (D'Argembeau, 2016; Lehner \& D'Argembeau, 2016). In particular, we suggest that

\footnotetext{
${ }^{1}$ It should be noted that belief in accuracy was not the main focus of the present study and it remains an open question to what extent "accuracy" appraisals are conceptually and empirically similar for past and for future events.
}

belief in occurrence is a critical component of the feeling that an event belongs to one's personal future and that this metacognitive appraisal acts in concert with autonoetic experience and belief in accuracy to create the full-blown subjective feeling of experiencing one's personal future. Our approach reflects the gathering momentum in the integration of nonmemorial aspects, and especially subjective feelings, as central components of the act of remembering and imagining to broaden our theoretical understanding of these complex mental activities (Klein, 2016; Scoboria et al., 2014). As such, the inclusion of these metacognitive appraisals in research on future thinking not only has methodological implications for future thinking assessment - to ensure that collected imagined events genuinely represent personal future events - but also appears promising to further elucidate the distinction between imaginary scenarios and personal future events at the theoretical level.

Although the present study represents an important first step in understanding the notion of belief in occurrence within episodic future thought, it should be noted that most reported events (especially past events) were associated with high levels of belief. This might be related to the use of general cue words and the absence of age restriction on generated events, which might have led participants to report highly accessible events (which are typically associated with high levels of belief in occurrence; Scoboria \& Talarico, 2013). The present findings might thus be restricted to this type of personal events, and it would be interesting in future studies to investigate whether similar relationships between subjective feelings and event features are observed for events that span a broader range of belief in occurrence. Furthermore, the fact that events were associated with high levels of belief in occurrence might explain some slight differences with previous studies in the pattern of results observed for past events. In particular, we found that the amount of sensory details contributed to belief in occurrence for past events, whereas sensory details were typically not predictive of belief in occurrence in previous studies (Scoboria et al., 2014; Scoboria, Talarico, et al., 2015); this could be due to differences in levels of belief across studies. Such differences could also explain why the correlation between personal plausibility and belief in occurrence for past events appeared weaker in the present study compared to previous work (Scoboria et al., 2014; Scoboria, Talarico, et al., 2015). As such, it would be interesting in future studies to expand the variability of belief in occurrence across past and future events to confirm and refine the current findings. Furthermore, it would also be interesting to measure belief and other subjective feelings using multiple item scales, which would enable to determine the reliability of measures for each construct and to use structural equation modeling to further test the proposed model (Scoboria et al., 2014; Scoboria, Talarico, et al., 2015).

As a final point, it is worth mentioning that documenting the existence of belief in occurrence for future events has also important implications for research exploring the functional 


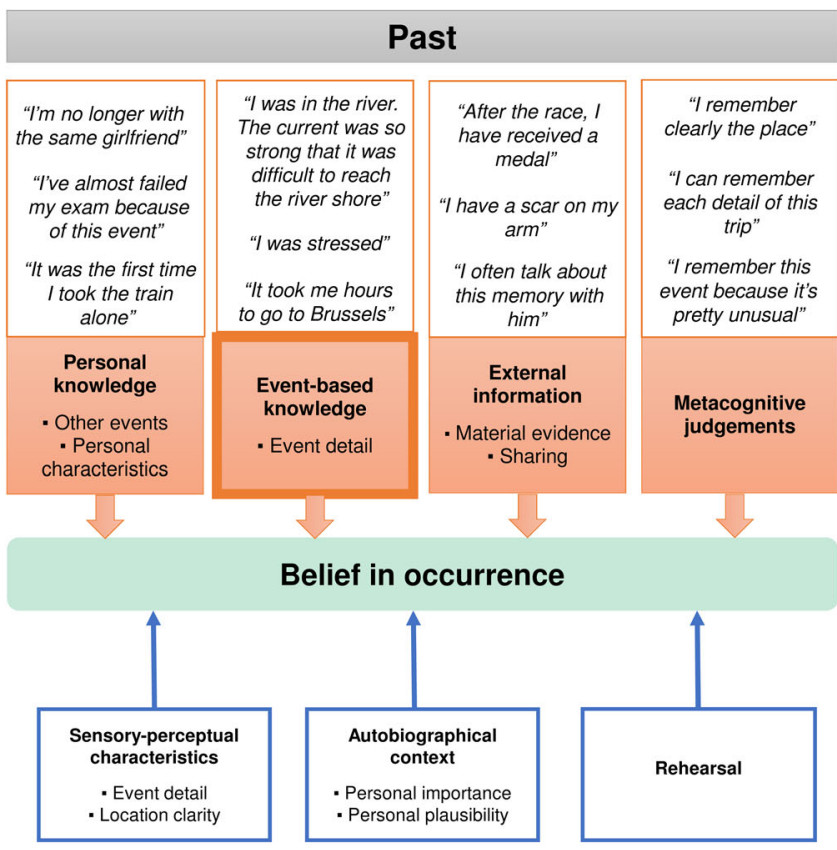

Sources of information

Fig. 2 Theoretical model of the sources of information (i.e., justifications) and the sources of variability (i.e., predictors) that shape belief in the occurrence of past and future events. In this model, belief in occurrence arises from attribution processes that rely on multiple sources of information and fluctuations in degrees of belief in occurrence are predicted by several sources of variability. These sources of information and variability show both common and distinct influences on belief in occurrence for past and future events. Common determinants of belief in occurrence for past and future events include their link with other events and personal characteristics, their personal importance and plausibility, as

implications of future thinking. Indeed, while there is considerable evidence that future thinking is involved in many aspects of our everyday life (Baumeister et al., 2016; Suddendorf \& Corballis, 2007), the factors that contribute to bridge the gap between mental representations and behaviors remain poorly understood. In this context, exploring the driving force of belief in occurrence on, for instance, motivation, decision making, and goal achievement, represents an avenue for future research. Studies along this line could stimulate applied research in domains such as education or clinical psychology. Indeed, the literature on education increasingly acknowledges that episodic future thinking supports academic motivation and behaviors (Husman, Brem, Banegas, Duchrow, \& Haque, 2015; Prabhakar, Coughlin, \& Ghetti, 2016). Whether belief in occurrence takes part in the relationship between future thinking and academic achievement, by influencing for example study effort or diligence, remains to be determined. In another domain, recent views in psychopathology assume that maladaptive future projections is a core process underlying anxiety (Miloyan \& Suddendorf, 2015) and depression (MacLeod, 2016; Roepke \& Seligman, 2015). Examining belief in occurrence attached to

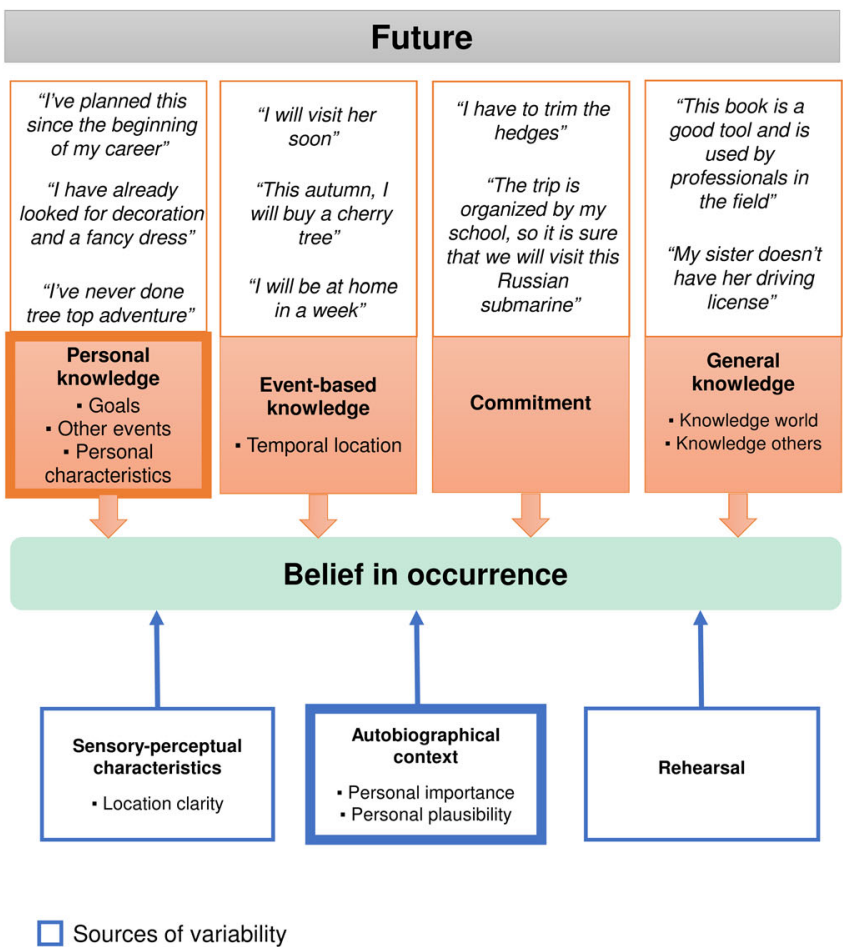

well as their location clarity and frequency of rehearsal. An important difference between the two temporal orientations, however, is that belief in the occurrence of future events mainly relies on their integration within an autobiographical context (and in particular, their relevance to personal goals), whereas belief in the occurrence of past events mostly depends on event details (and also to some extent on metacognitive judgments or external information). Thicker lines indicate sources of information and variability that play a stronger role in shaping belief in occurrence for past or future events. (Color figure online)

maladaptive future projections offers an interesting approach to further our understanding of the cognitive mechanisms contributing to psychopathological conditions and may inspire new therapeutic approaches aiming to restructure maladaptive future thinking, for instance, by challenging unrealistic prospections or by elaborating on the personal meaning and purpose of future events (Seligman, Railton, Baumeister, \& Sripada, 2013).

Acknowledgements Alexandra Ernst is a Marie Curie COFUND postdoctoral fellow supported by a research grant from the European Union and the University of Liege. Arnaud D'Argembeau is Senior Research Associate of the Fonds de la Recherche Scientifique (F.R.S.-FNRS), Belgium. We thank J. Duruisseau, C. Marcotte, N. Lebbate, L. Lamine and L. Machuraux for their help with participants' recruitment and testing.

\section{Appendix 1. Cue words used to elicit past and future events}

A total of 20 cue words were divided into two lists and the assignment of these two lists to the past and future conditions 
was counterbalanced across participants. For each list, cue words were presented in French (English translations are provided in square brackets), in a random order.

\section{List 1}

Voiture [Car]; Livre [Book]; Vacances [Holiday]; Chien [Dog]; Fête [Party]; Loisir [Hobbies]; Fleur [Flower]; Visite [Visit]; Rivière [River]; Ami [Friend]

\section{List 2}

Train [Train]; Famille [Family]; Sortie [Outing]; Montagne [Mountain]; Invitation [Invitation]; Arbre [Tree]; Voyage [Journey]; Oiseau [Bird]; Travail [Work]; Bouteille [Bottle]

\section{Appendix 2. Rating scales used to assess subjective feelings and event features}

Items were administered in French (the English translation of each item is indicated in square brackets).

\section{Belief in occurrence}

1. En me rappelant (en m'imaginant) cet événement, j'ai le sentiment qu'il a réellement eu lieu (va réellement avoir lieu) $(1=$ pas du tout, $7=$ très fortement $)$

[While remembering (imagining) this event, I feel that it actually occurred (will actually occur) $(1=$ not at all, $7=$ very strongly)]

\section{Autonoetic experience}

2. En me rappelant (en m'imaginant) cet événement, j'ai le sentiment de revivre (vivre) l'événement comme si j'y étais $(1=$ pas du tout, $7=$ très fortement $)$

[While remembering (imagining) this event, I feel that I am reexperiencing (experiencing) the situation, as if I was there $(1=$ not at all, $7=$ very strongly $)]$

3. En me rappelant de (en m'imaginant) cet événement, j'ai l'impression de retourner dans le passé (d'aller dans le futur) et de me retrouver (trouver) au moment où cet événement s'est produit (se produira) $(1=$ pas du tout, 7 $=$ très fortement $)$

[While remembering (imagining) this event, I feel that I travel back (forward) in time and that I am right at the moment when this event happened (will happen) $(1=$ not at all, $7=$ absolutely) $]$

\section{Belief in accuracy}

4. Dans quelle mesure pensez-vous que cet événement s'est déroulé (se déroulera) exactement comme vous vous en souvenez (vous l'imaginez)? $(1=$ pas du tout, 7 = très exactement)

[To what extent do you think that this event took (will take) place exactly as you remember (imagine) it $(1=n o t$ at all, 7 = very accurately) $]$

\section{Sensory details}

5. Ma représentation de cet événement comporte des détails sensoriels (je peux voir, entendre ou percevoir ce qui s'est passé (va se passer) $)(1=$ pas du tout, 7 = énormément $)$

[My representation of this event contains sensory details (I can see, hear or perceive what happened (will happen)) $(1=$ not at all, $7=$ alot $)]$

\section{Location}

6. Lorsque je pense à cet événement, je vois le lieu/l'environnement où il a eu lieu (va avoir lieu) $(1=$ pas du tout, 7 = très clairement)

[As I think about this event, I can see the location/ setting where it took (will take) place $(1=$ not at all, 7 $=$ extremely clear $)]$

\section{Familiarity}

7. Cet événement implique des lieux, personnes ou objets qui me sont familiers $(1=$ pas du tout familiers, $7=$ extrêmement familiers)

[This event involves places, people or objects which are familiar to me $(1=$ not at all familiar, $7=$ extremely familiar)]

\section{Emotional valence}

8. En me rappelant (imaginant) cet événement, je ressens une émotion : $(-3=$ très négative, $0=$ neutre, $+3=$ très positive)

[While remembering (imagining), the emotion I feel is: $(-3=$ very negative, $0=$ no emotion, $+3=$ very positive $)]$

\section{Emotional intensity}

9. En me rappelant (imaginant) cet événement, je ressens une émotion: $(1=$ pas du tout intense, $7=$ très intense $)$ 
[While remembering (imagining) this event, the emotion I feel is: $(1=$ not at all intense, $7=$ very intense $)$ ]

\section{Personal importance}

10. Cet événement est un moment important pour moi, par rapport à mes buts, mes valeurs, etc. $(1=$ pas du tout important, 7 = très important)

[This event is important to me, in relation to my goals, my values, etc. $(1=$ not at all important, $7=$ very important)]

\section{Link with other personal events}

11. Lorsque je me suis rappelé (j'ai imaginé) cet événement, j'ai également pensé à d'autres événements (des évènements que j'ai vécus dans le passé ou d'autres événements que je pourrais vivre dans l'avenir) $(1=$ pas du tout, $7=$ très fortement $)$

[As I remembered (imagined) this event, I also thought about other events (some events that I experienced in the past or other events that I might experience in the future). $(1=$ not at all, $7=$ very strongly $)]$

\section{Rehearsal}

12. J'ai déjà pensé à cet événement avant de l'évoquer aujourd'hui $(1=$ jamais, 7 = très souvent $)$

[I already thought about this event before evoking it today $(1=$ never, $7=$ very often $)]$

13. J'ai déjà partagé et échangé sur cet événement avec d'autres personnes avant de l'évoquer aujourd'hui $(1=$ jamais, 7 = très souvent)

[I already shared and spoke about this event with other persons before evoking it today $(1=$ never, $7=$ very often)]

\section{Similarity}

14. Dans ma vie en général, j'ai l'occasion de vivre des événements semblables à celui-ci $(1=$ jamais, $7=$ très souvent)

[In my life in general, I experience events similar to this one $(1=$ never, $7=$ very often $)]$

\section{General plausibility}

15. S'agit-il d'un événement qui pourrait arriver de manière plausible à la plupart des gens ? $(1=$ pas $d u$ tout plausible, $7=$ très plausible $)$

[Is this an event that could plausibly happen to most people? $(1=$ not at all plausible, $7=$ extremely plausible)]

\section{Personal Plausibility}

16. Dans quelle mesure est-il plausible que vous, personnellement, ayez vécu (serez amené à vivre) cet événement ? $(1=$ pas du tout plausible, $7=$ très plausible)

[How plausible is it that you, personally, experienced (would experience) this event? ( 1 = not at all plausible, $7=$ extremely plausible $)]$

\section{Subjective temporal distance}

17. Les événements dont nous rappelons (que nous imaginons) peuvent nous sembler plus ou moins proches dans le temps (comme s'ils s'étaient produits récemment (allaient se produire bientôt) ou au contraire il y a (dans) longtemps), indépendamment du moment où ils se sont produits (vont se produire). Quel est votre sentiment subjectif de proximité par rapport à cet événement $?(1=$ très proche, $7=$ très éloigné $)$

[Sometimes events that we remember (imagine) feel more or less close in time (as if they happened very recently (will happen soon) or, on the contrary, a long time ago (in a long time), regardless of when events actually happened (will actually happen). How close does the event feel to you? $(1=$ very close, $7=$ very distant)]

\section{References}

Addis, D. R., Cheng, T., Roberts, R. P., \& Schacter, D. L. (2011). Hippocampal contributions to the episodic simulation of specific and general future events. Hippocampus, 21, 1045-1052. doi:10. 1002/hipo. 20870

Addis, D. R., Wong, A. T., \& Schacter, D. L. (2007). Remembering the past and imagining the future: Common and distinct neural substrates during event construction and elaboration. Neuropsychologia, 45, 1363-1377. doi:10.1016/j.neuropsychologia.2006.10.016

Addis, D. R., Wong, A. T., \& Schacter, D. L. (2008). Age-related changes in the episodic simulation of future events. Psychological Science, 19, 33-41. doi:10.1111/j.1467-9280.2008.02043.x 
Baumeister, R. F., Vohs, K. D., \& Oettingen, G. (2016). Pragmatic prospection: How and why people think about the future. Review of General Psychology, 20, 3-16. doi:10.1037/gpr0000060

Berntsen, D., \& Jacobsen, A. S. (2008). Involuntary (spontaneous) mental time travel into the past and future. Consciousness and Cognition, 17, 1093-1104. doi:10.1016/j.concog.2008.03.001

Botzung, A., Denkova, E., \& Manning, L. (2008). Experiencing past and future personal events: Functional neuroimaging evidence on the neural bases of mental time travel. Brain and Cognition, 66, 202212. doi:10.1016/j.bandc.2007.07.011

Braun, V., \& Clarke, V. (2006). Using thematic analysis in psychology. Qualitative Research in Psychology, 3, 77-101. doi:10.1191/ 1478088706qp063oa

Brédart, S., \& Bouffier, M. (2016). Nonbelieved memories in middleaged and older people. Consciousness and Cognition, 42, 352357. doi:10.1016/j.concog.2016.04.009

Conway, M. A. (2005). Memory and the self. Journal of Memory and Language, 53, 594-628. doi:10.1016/j.jml.2005.08.005

Conway, M. A., Loveday, C., \& Cole, S. N. (2016). The rememberingimagining system. Memory Studies, 9, 256-265. doi:10.1177/ 1750698016645231

D'Argembeau, A. (2015). Knowledge structures involved in episodic future thinking. In A. Feeney \& V. A. Thompson (Eds.), Reasoning as memory (pp. 128-145). Hove, UK: Psychology Press.

D'Argembeau, A. (2016). The role of personal goals in future-oriented mental time travel. In K. Michaelian, S. B. Klein, \& K. K. Szpunar (Eds.), Seeing the future: Theoretical perspectives on futureoriented mental time travel (pp. 199-214). New York, NY: Oxford University Press. doi:10.1093/acprof:oso/9780190241537.003. 0010

D'Argembeau, A., \& Mathy, A. (2011). Tracking the construction of episodic future thoughts. Journal of Experimental Psychology. General, 140, 258-271. doi:10.1037/a0022581

D'Argembeau, A., \& Van Der Linden, M. (2004). Phenomenal characteristics associated with projecting oneself back into the past and forward into the future: Influence of valence and temporal distance. Consciousness and Cognition, 13, 844-858. doi:10.1016/j.concog. 2004.07.007

D'Argembeau, A., \& Van der Linden, M. (2006). Individual differences in the phenomenology of mental time travel: The effect of vivid visual imagery and emotion regulation strategies. Consciousness and Cognition, 15, 342-350. doi:10.1016/j.concog.2005.09.001

D'Argembeau, A., \& Van der Linden, M. (2012). Predicting the phenomenology of episodic future thoughts. Consciousness and Cognition, 21, 1198-1206. doi:10.1016/j.concog.2012.05.004

De Brigard, F., \& Giovanello, K. S. (2012). Influence of outcome valence in the subjective experience of episodic past, future, and counterfactual thinking. Consciousness and Cognition, 21, 1085-1096.

De Brigard, F., Giovanello, K. S., Stewart, G. W., Lockrow, A. W., O’Brien, M. M., \& Spreng, R. N. (2016). Characterizing the subjective experience of episodic past, future, and counterfactual thinking in healthy younger and older adults. The Quarterly Journal of Experimental Psychology, 69, 2358-2375.

de Vito, S., Gamboz, N., \& Brandimonte, M. A. (2012). What differentiates episodic future thinking from complex scene imagery? Consciousness and Cognition, 21, 813-823. doi:10.1016/j.concog. 2012.01.013

Ernst, A., Blanc, F., De Seze, J., Sellal, F., Chauvin, B., \& Manning, L. (2014). Impaired mental simulation of specific past and future personal events in non-depressed multiple sclerosis patients. Journal of the Neurological Sciences, 345, 68-74. doi:10.1016/j.jns.2014.07. 007

Faul, F., Erdfelder, E., Lang, A. G., Buchner, A., \& Kiel, C. (2007). G*Power3: A flexible statistical power analysis program for the social, behavioral, and biomedical sciences. Behavioral Research Methods, 39, 175-191. doi:10.3758/bf03193146
Fitzgerald, J. M., \& Broadbridge, C. L. (2013). Latent constructs of the autobiographical memory questionnaire: A recollection-belief model of autobiographical experience. Memory, 21, 230-248. doi:10. 1080/09658211.2012.725736

Goldstein, H. (2011). Multilevel statistical models (4th ed.). Chichester, UK: Wiley.

Gronau, N., Neta, M., \& Bar, M. (2008). Integrated contextual representation for objects' identities and their locations. Journal of Cognitive Neuroscience, 20, 371-388. doi:10.1162/jocn.2008.20027

Hassabis, D., Kumaran, D., Vann, S. D., \& Maguire, E. A. (2007). Patients with hippocampal amnesia cannot imagine new experiences. Proceedings of the National Academy of Sciences of the United States of America, 104, 1726-1731. doi:10.1073/pnas. 0610561104

Hassabis, D., \& Maguire, E. A. (2009). The construction system of the brain. Philosophical Transactions of the Royal Society of London, Series B: Biological Sciences, 364, 1263-1271. doi:10.1093/acprof: oso/9780195395518.003.0026

Holland, A. C., Addis, D. R., \& Kensinger, E. A. (2011). The neural correlates of specific versus general autobiographical memory construction and elaboration. Neuropsychologia, 49, 3164-3177. doi: 10.1016/j.neuropsychologia.2011.07.015

Hruschka, D. J., Schwartz, D., St. John, D. C., Picone-Decaro, E., Jenkins, R. A., \& Carey, J. W. (2004). Reliability in coding openended data: Lessons learned from HIV behavioral research. Field Methods, 16, 307-331. doi:10.1177/1525822X04266540

Husman, J., Brem, S. K., Banegas, S., Duchrow, D. W., \& Haque, S. (2015). Learning and future time perspective: The promise of the future-Rewarding in the present. In M. Stolarski, N. Fieulaine, \& W. van Beek (Eds.), Time perspective theory; Review, research and application. essays in honor of Philip G. Zimbardo (pp. 131-141). doi:10.1007/978-3-319-07368-2

Irish, M., \& Piguet, O. (2013). The pivotal role of semantic memory in remembering the past and imagining the future. Frontiers in Behavioral Neuroscience, 7, 27. doi:10.3389/fnbeh.2013.00027

James, W. (1890). The principles of psychology. Cambridge, MA: Harvard University Press.

Johnson, M. K. (2006). Memory and reality. The American Psychologist, 61, 760-771. doi:10.1037/0003-066X.61.8.760

Johnson, M. K., Hashtroudi, S., \& Lindsay, D. S. (1993). Source monitoring. Psychological Bulletin, 114, 3-28. doi:10.1037/0033-2909. 114.1.3

Klein, S. B. (2016). Autonoetic consciousness: Reconsidering the role of episodic memory in future-oriented self-projection. The Quarterly Journal of Experimental Psychology, 69, 381-401. doi:10.1080/ 17470218.2015.1007150

Klein, S. B., Loftus, J., \& Kihlstrom, J. F. (2002). Memory and temporal experience: The effects of episodic memory loss on an amnesic patient's ability to remember the past and imagine the future. Social Cognition, 20, 353-379. doi:10.1521/soco.20.5.353.21125

Lehner, E., \& D'Argembeau, A. (2016). The role of personal goals in autonoetic experience when imagining future events. Consciousness and Cognition, 42, 267-276. doi:10.1016/j.concog.2016.04.002

Maas, C. J., \& Hox, J. (2005). Sufficient sample sizes for multilevel modeling. Methodology, 1, 86-92. doi:10.1027/1614-2241.1.3.86

MacLeod, A. K. (2016). Prospection, well-being and memory. Memory Studies, 9, 266-274. doi:10.1177/1750698016645233

Mazzoni, G., Scoboria, A., \& Harvey, L. (2010). Nonbelieved memories. Psychological Science, 21, 1334-1340. doi:10.1177/ 0956797610379865

McDonough, I. M., \& Gallo, D. A. (2010). Separating past and future autobiographical events in memory: Evidence for a reality monitoring asymmetry. Memory \& Cognition, 38, 3-12. doi:10.3758/MC.38.1.3

Miloyan, B., \& Suddendorf, T. (2015). Feelings of the future. Trends in Cognitive Sciences, 19, 196-200. doi:10.1016/j.tics.2015.01.008 
O'Brien, F., \& Cousineau, D. (2014). Representing Error bars in withinsubject designs in typical software packages. The Quantitative Methods for Psychology, 10, 56-67. doi:10.20982/tqmp.10.1.p056

Perrin, D. (2016). Asymmetries in subjective time. In K. Michaelian, S. B. Klein, \& K. K. Szpunar (Eds.), Seeing the future: Theoretical perspectives on future-oriented mental time travel (pp. 39-61). New York, NY: Oxford University Press. doi:10.1093/acprof:oso/ 9780190241537.003.0003

Prabhakar, J., Coughlin, C., \& Ghetti, S. (2016). The neurocognitive development of episodic prospection and its implications for academic achievement. Mind, Brain, and Education, 10, 196-206. doi: 10.1111/mbe. 12124

Rasbash, J., Charlton, C., Browne, W. J., Healy, M., \& Cameron, B. (2009). MLwiN version 2.1. Bristol, UK: Centre for Multilevel Modelling, University of Bristol.

Rasmussen, A. S., \& Habermas, T. (2011). Factor structure of overall autobiographical memory usage: The directive, self and social functions revisited. Memory, 19, 597-605. doi:10.1080/09658211.2011. 592499

Roepke, A. M., \& Seligman, M. E. P. (2015). Depression and prospection. British Journal of Clinical Psychology, 55, 23-48. doi:10.1111/bjc. 12087

Rubin, D. C. (2006). The basic-systems model of episodic memory. Perspectives on Psychological Science, 1, 277-311. doi:10.1111/j. 1745-6916.2006.00017.x

Rubin, D. C., Schrauf, R. W., \& Greenberg, D. L. (2003). Belief and recollection of autobiographical memories. Memory \& Cognition, 31, 887-901. doi:10.3758/BF03196443

Schacter, D. L. (2012). Adaptive constructive processes and the future of memory. American Psychologist, 67, 603-613. doi:10.1037/ a0029869

Schacter, D. L., \& Addis, D. R. (2007). The cognitive neuroscience of constructive memory: Remembering the past and imagining the future. Philosophical Transactions of the Royal Society of London, Series B: Biological Sciences, 29, 773-786. doi:10.1098/rstb.2007. 2087

Schacter, D. L., Addis, D. R., Hassabis, D., Martin, V. C., Spreng, R. N., \& Szpunar, K. K. (2012). The future of memory: Remembering, imagining, and the brain. Neuron, 76, 677-694. doi:10.1016/j. neuron.2012.11.001

Scoboria, A., Boucher, C., \& Mazzoni, G. (2015). Reasons for withdrawing belief in vivid autobiographical memories. Memory, 23, 545562. doi:10.1080/09658211.2014.910530

Scoboria, A., Jackson, D. L., Talarico, J., Hanczakowski, M., Wysman, L., \& Mazzoni, G. (2014). The role of belief in occurrence within autobiographical memory. Journal of Experimental Psychology: General, 143, 1242-1258. doi:10.1037/a0034110

Scoboria, A., Mazzoni, G., Kirsch, I., \& Relyea, M. (2004). Plausibility and belief in autobiographical memory. Applied Cognitive Psychology, 18, 791-807. doi:10.1002/acp.1062
Scoboria, A., \& Pascal, L. (2016). Dissociating appraisals of accuracy and recollection in autobiographical remembering. Journal of Experimental Psychology: Learning, Memory, and Cognition, 42, 1068-1077. doi:10.1037/xlm0000230

Scoboria, A., \& Talarico, J. M. (2013). Indirect cueing elicits distinct types of autobiographical event representations. Consciousness and Cognition, 22, 1495-1509. doi:10.1016/j.concog.2013.09.007

Scoboria, A., Talarico, J. M., \& Pascal, L. (2015). Metamemory appraisals in autobiographical event recall. Cognition, 136, 337-349. doi:10.1016/j.cognition.2014.11.028

Scoboria, A., \& Wilson, T. (2011). Memory for future gambling wins. Psychology of Addictive Behaviors, 25, 565-572. doi:10.1037/ a0022707

Seligman, M. E. P., Railton, P., Baumeister, R. F., \& Sripada, C. (2013). Navigating into the future or driven by the past. Perspectives on Psychological Science, 8, 119-141. doi:10.1177/1745691612474317

Spreng, R. N., \& Levine, B. (2006). The temporal distribution of past and future autobiographical events across the lifespan. Memory \& Cognition, 34, 1644-1651.

Suddendorf, T., \& Corballis, M. C. (2007). The evolution of foresight: What is mental time travel, and is it unique to humans? Behavioral and Brain Sciences, 30, 299-313. doi:10.1017/S0140525X07001975

Summerfield, J. J., Hassabis, D., \& Maguire, E. A. (2010). Differential engagement of brain regions within a 'core' network during scene construction. Neuropsychologia, 48(5), 1501-1509. doi:10.1016/j. neuropsychologia.2010.01.022

Sutin, A. R., \& Robins, R. W. (2007). Phenomenology of autobiographical memories: The memory experiences questionnaire. Memory, 15, 390-411. doi:10.1080/09658210701256654

Szpunar, K. K. (2010). Episodic future thought: An emerging concept. Perspectives on Psychological Science, 5, 142-162. doi:10.1177/ 1745691610362350

Szpunar, K. K., \& Schacter, D. L. (2013). Get real: Effects of repeated simulation and emotion on the perceived plausibility of future experiences. Journal of Experimental Psychology: General, 142, 323327. doi: $10.1037 / \mathrm{a} 0028877$

Szpunar, K. K., Spreng, R. N., \& Schacter, D. L. (2014). A taxonomy of prospection: Introducing an organizational framework for futureoriented cognition. Proceedings of the National Academy of Sciences, 111, 18414-18421. doi:10.1073/pnas.1417144111

Tulving, E. (1985). Memory and consciousness. Canadian Psychology, 26, 1-12. doi: $10.1037 / \mathrm{h} 0080017$

Von Eye, A., \& Von Eye, M. (2008). On the marginal dependency of Cohen's k. European Psychologist, 13, 305-315. doi:10.1027/10169040.13.4.305

Weiler, J. A., Suchan, B., \& Daum, I. (2010). Foreseeing the future: Occurrence probability of imagined future events modulates hippocampal activation. Hippocampus, 20, 685-690. 